\title{
Midday stomatal closure in Norway spruce-reactions in the upper and lower crown
}

\author{
R. ZWEIFEL, ${ }^{1,2}$ J. P. BÖHM ${ }^{3}$ and R. HÄSLER ${ }^{4}$ \\ ${ }^{1}$ Institute of Plant Sciences, University of Bern, Altenbergrain 21, CH-3013 Bern, Switzerland \\ 2 Author to whom correspondence should be addressed (roman.zweifel@ips.unibe.ch) \\ ${ }^{3}$ Giessenstrasse 11, CH-8606 Bubikon, Switzerland \\ ${ }^{4}$ Swiss Federal Research Institute WSL, Zürcherstrasse 111, CH-8903 Birmensdorf, Switzerland
}

Received September 18, 2001; accepted March 28, 2002; published online October 1, 2002

Summary We used local microclimatic conditions and twig sap flow rates to interpret midday stomatal closure in the canopies of two 250-year-old Norway spruce (Picea abies (L.) Karst.) trees at a subalpine site in the Swiss Alps $(1650 \mathrm{~m}$ a.s.1.). Both trees showed midday stomatal closure on most clear summer days, despite the permanently wet soil. We used a modified Penman-Monteith formula to simulate potential transpiration of single twigs $\left(\mathrm{ET}_{\mathrm{T}}\right)$ based on high-resolution temporal and spatial microclimate data obtained both inside and outside the crowns. Comparison of calculated $\mathrm{ET}_{\mathrm{T}}$ values and measured twig sap flow rates enabled us to pinpoint the occurrence of midday stomatal closure and the microclimatic conditions present at that time.

We found that vapor pressure deficit (and for upper-crown twigs, $\mathrm{ET}_{\mathrm{T}}$ ) largely explained the timing of initial midday stomatal closure but gave no explanation for the different patterns of stomatal behavior after initial closure in upper- and lower-crown twigs. After the initial stomatal closure, uppercrown twigs maintained high transpiration rates by continuously regulating stomatal aperture, whereas stomatal aperture decreased rapidly in lower-crown twigs and did not increase later in the day. Midday stomatal closure in lower-crown twigs occurred on average $1 \mathrm{~h}$ later than in upper-crown twigs. However, the microclimate at the time of initial stomatal closure was similar at both crown locations except that lower-crown twigs received significantly less solar radiation than uppercrown twigs both at the time of initial stomatal closure and afterwards. High rates of sap flow in twigs did not always lead to stomatal closure and therefore could not explain the phenomenon. We conclude that stomatal conductance can be modeled accurately only when both local microclimatic conditions and tree water status are known. Further, we hypothesize that both the quantity and quality of light play an important role in the reopening of closed stomata during the day.

Keywords: evapotranspiration, Penman-Monteith, stomatal conductance, Picea abies, water relations.

\section{Introduction}

Trees maintain their water balance in both wet and dry environments. Regulation of stomatal conductance is the most important mechanism by which plants regulate water loss during periods of high evaporative demand. Despite the importance of this process for tree survival and competition, the underlying physiological mechanisms are still unclear and the role of microclimate remains controversial (Whitehead 1998). Messenger molecules (e.g., abscisic acid (ABA)) in addition to hydraulic factors, water potential gradients and boundary layer properties may be involved. There is considerable evidence for each of these components (ABA: Gowing et al. 1990, Khalil and Grace 1993, Shashidhar et al. 1996; hydraulic conductance: Sperry et al. 1993, Whitehead et al. 1996, Meinzer et al. 1997, Oren et al. 2001; plant water potential: Tardieu et al. 1993, Dewar 1995, Mencuccini et al. 2000; soil water content: Jackson et al. 1995, Irvine et al. 1998, Oren and Pataki 2001; microclimatic conditions: Loustau et al. 1996, Oren et al. 1999, Hogg et al. 2000; boundary layer conductance: Meinzer and Grantz 1991), but no consensus has emerged on how to bring together the different results in order to explain the regulation of stomatal aperture by internal and external factors. Johnson et al. (1991), Tardieu and Davies (1993) and Williams et al. (1996) developed interactive models incorporating energy balance, stomatal conductance, photosynthesis, hydraulic properties of the flow path and a component that describes a root-shoot signal. Nevertheless, even these complex models do not fully explain how microclimate influences stomatal behavior. The discovery of a biochemical system that senses either messenger molecules (e.g., ABA), or changes in hydraulic conductivity or water potential gradients (Sharpe et al. 1987) would be a major breakthrough. The mechanistic model of Dewar (1995) is a first step toward explaining empirical relationships between microclimate and stomatal conductance by invoking physiological sensing systems.

The role of microclimate in regulating stomatal conductance in trees may be obscured if microclimatic variation within the canopy is ignored, because it is the local conditions 
at the leaf surface that have the greatest influence on transpiration and stomatal aperture (Jarvis and McNaughton 1986, Meinzer and Grantz 1991, Leuning 1995, Meinzer et al. 1996). This is confirmed by the finding that patterns of transpiration within single crowns are related to within-crown microclimatic variation in Norway spruce (Picea abies (L.) Karst.) (Alsheimer et al. 1998, Herzog et al. 1998). Corresponding within-crown variation in stomatal opening can also be expected (Van Kraalingen 1990, Beyschlag et al. 1994).

The relationship between microclimate and stomatal conductance in trees may be further obscured if stomatal conductance is estimated from below-crown stem sap flow measurements, which integrate the responses of parts of the crown that may be experiencing quite dissimilar microclimatic conditions. It is conceivable that a complex flow-and-storage system exists such that the parts of a tree's crown (e.g., twigs, needles or single stomata) are more or less autonomous, reacting to local conditions in ways that avoid the development of extreme water stress that could result in cavitation in the flow path (Zweifel and Häsler 2001). Nevertheless, each part of the crown is hydraulically coupled to the others and therefore the stomatal response of a twig is determined by both its immediate external environment and the water status of the entire tree. Thus, twigs exposed to similar microclimatic conditions on the same tree do not necessarily respond identically because they may receive different internal signals (e.g., local water status, concentration of biochemical messengers). It is therefore unlikely that a whole-tree stomatal conductance formula based on sap flow and microclimatic data integrated for the entire tree will lead to a clear picture of the mechanisms controlling stomatal behavior.

Our study of stomatal behavior of single twigs in mature Norway spruce trees focused on the rapid stomatal closure occurring around noon (midday stomatal closure). We made high-resolution measurements of temporal and spatial gradients in microclimate within and outside the tree crowns. We simulated leaf surface conditions and potential transpiration of single twigs $\left(\mathrm{ET}_{\mathrm{T}}\right)$ with a modified Penman-Monteith formula based on observed microclimate data and compared them with measured sap flow rates in twigs $(F)$. We discuss the microclimatic conditions at the time of initial stomatal closure in terms of recently suggested models (Meinzer and Grantz 1991, Dewar 1995, Monteith 1995, Bond and Kavanagh 1999) and consider the characteristics that a stomatal regulatory system must have to explain the phenomenon observed.

\section{Materials and methods}

\section{Study site and trees}

The study site was located at the foot of Mt. Seehorn in a subalpine Norway spruce forest at $1640 \mathrm{~m}$ a.s.l. near Davos, Switzerland $\left(46^{\circ} 48^{\prime} 59^{\prime \prime} \mathrm{N}, 9^{\circ} 51^{\prime} 25^{\prime \prime} \mathrm{E}\right)$, where trees have been continuously investigated for water relations and carbon fixation since 1985, to provide a data set that offers extensive historical information (Häsler et al. 1991, Häsler 1992, Herzog 1995, Zweifel 1999). The present study involved two mature
( 250-year-old) Norway spruce trees and their microclimate. A scaffold $(22 \mathrm{~m})$ and a tower $(35 \mathrm{~m})$ gave access to the entire crowns of these trees. Data for analysis were collected from May to October 1995. Details of stem size, tree height and twig biomass are given in Table 1.

\section{Microclimate measurements}

Two profiles of net radiation $\left(R_{\mathrm{n}}\right)$, dew point temperature $\left(T_{\mathrm{D}}\right)$, wind velocity $\left(u_{\mathrm{z}}\right)$ and air temperature $\left(T_{\mathrm{a}}=\right.$ temperature between trees, $T_{\mathrm{T}}=$ temperature at the twig surface) were measured. Sensor types and measurement locations are listed in Table 2. Vapor pressure deficit of the air (VPD) was calculated from the dew point temperature. One profile represents the microclimatic differences between the trees, the other the microclimatic conditions at the surface of the investigated twigs. The sensors in the crown were located about $0.05 \mathrm{~m}$ above the twig surface on the southeast side of the tree, $1 \mathrm{~m}$ inside the outermost edge of the crown. Also measured were air pressure $(P)$, soil water potential $\left(\Psi_{\mathrm{S}}\right)$ and soil temperature $\left(T_{\mathrm{S}}\right)$. All measurements were recorded at 10-s intervals and 10-min means were calculated. On 7 days, the time course of needle water potential $\left(\Psi_{\mathrm{N}}\right)$ of the twigs was measured with a Scholander pressure chamber (Scholander et al. 1965).

\section{Sap flow measurements}

Sap flow was continuously assessed at the base of six twigs by heat balance gauges (Dynagage, Dynamax, Houston, TX). We followed the procedure for mounting and handling the gauges described by Herzog et al. (1997), except that the silicon layer between the thermocouples and the stem surface was separated from the bark by a thin layer of plastic foil, to exclude possible damage to the bark by the silicon compound (Wiltshire et al. 1995). The sap flow gauges were mounted on the twigs listed in Table 1.

Table 1. Tree height $(H)$, height above ground of the individual twigs (h), diameter of the stem at $1.5 \mathrm{~m}$ above ground (ØStem) and diameter of twigs at the base (ØTwig) are given for the two 250-year-old Norway spruce trees investigated. Dry weight of needle biomass $\left(w_{N}\right)$ was measured on one harvested twig (C.182) and estimated for all others. The twigs investigated were on the southeast side of each tree and were equipped with sap flow gauges. Twig B.61b was shaded for most of the day; the other twigs were at least partially exposed to direct sunlight.

\begin{tabular}{llclll}
\hline Tree & Twig & $\begin{array}{l}H,(h) \\
(\mathrm{m})\end{array}$ & $\begin{array}{c}\varnothing \text { Stem } \\
(\mathrm{m})\end{array}$ & $\begin{array}{l}\varnothing \text { Twig } \\
(\mathrm{m})\end{array}$ & $\begin{array}{l}w_{\mathrm{N}} \\
(\mathrm{g})\end{array}$ \\
\hline B & - & 23 & 0.294 & - & - \\
& B.61b & $(18)$ & - & 0.0186 & 165 \\
& B.62a & $(18)$ & - & 0.0290 & 185 \\
& B.5a & $(8)$ & - & 0.0297 & 290 \\
& B.4b & $(8)$ & - & 0.0290 & 235 \\
C & - & 24 & 0.369 & - & - \\
& C.181 & $(18)$ & - & 0.0321 & 410 \\
& C.182 & $(18)$ & - & 0.0295 & 460 \\
\hline
\end{tabular}


Table 2. Sensor types and measurement locations.

\begin{tabular}{llllr}
\hline Variable & Abbreviation & Sensor type & Measurement location: height above ground (m) \\
\cline { 4 - 5 } & & & In tree & On tower \\
\hline Net radiation & $R_{\mathrm{n}}$ & Pyranometer & $8,10,18$ & $2,10,20,25,35$ \\
Dew point temperature & $T_{\mathrm{D}}$ & Dew point mirror & $8,10,14,18(2)^{1}, 22$ & $2,10,20,25,35$ \\
Wind speed & $u_{\mathrm{z}}$ & Anemometer & $8,10,18$ & $2,10,20,25,35$ \\
Air temperature & $T_{\mathrm{a}}$ (Tower), & PT100 & $8,10,14,18(2), 22$ & $2,10,20,25,35$ \\
Soil temperature & $T_{\mathrm{T}}$ (Twigs) & & & $-0.05,-0.15,-0.25$ \\
Soil water potential & $T_{\mathrm{S}}$ & Thermistor & $-0.2(6),-0.5(6),-0.7(6)$ & \\
& $\Psi_{\mathrm{S}}$ & Tensiometer & & \\
Needle water potential & $\Psi_{\mathrm{N}}$ & (with pressure transducer) & & \\
Air pressure & $P$ & Scholander chamber & 8,18 & \\
\hline
\end{tabular}

${ }^{1}$ Number in brackets refers to the number of sensors at this height.

\section{Stomatal conductance}

Relative stomatal conductance $\left(g_{\mathrm{s}} ; \%\right)$ was assessed as the ratio of measured sap flow rates to calculated potential twig-specific transpiration rates $\left(F / \mathrm{ET}_{\mathrm{T}}\right)$. Twig-specific maximum stomatal conductance $\left(g_{\text {smax }}\right)$ was calculated as the reciprocal of minimum twig resistance $\left(r_{\mathrm{cTmin}}\right)$, which was obtained by optimizing a mathematical algorithm to fit $\mathrm{ET}_{\mathrm{T}}$ to $F$. Specific twig conductance $\left(k_{\mathrm{T}}\right)$ was calculated as the reciprocal of $r_{\mathrm{cTmin}}$ divided by the twig surface area $\left(Z_{\mathrm{T} 0}\right)$.

\section{Modeling potential twig transpiration}

Calculation of the potential transpiration of single twigs was based on the single-leaf model of Penman-Monteith (Penman 1948, Monteith 1965):

$$
\lambda \mathrm{ET}=\frac{\Delta\left(R_{\mathrm{n}}-G\right)+\rho c_{\mathrm{p}}\left(\frac{e_{\mathrm{s}}-e_{\mathrm{a}}}{r_{\mathrm{a}}}\right)}{\Delta+\gamma\left(1+\frac{r_{\mathrm{c}}}{r_{\mathrm{a}}}\right)},
$$

where $\lambda E T$ is vapor flux density $\left(\mathrm{MJ} \mathrm{m}^{-2} \mathrm{~s}^{-1}\right), \Delta$ is the slope of the saturation vapor pressure curve at the actual temperature $\left(T_{\mathrm{a}}\right), R_{\mathrm{n}}$ is net radiation flux, $G$ is soil heat flux density, $\rho$ is air density $\left(\mathrm{kg} \mathrm{m}^{-3}\right), c_{\mathrm{p}}$ is specific heat of the air $\left(1.01 \times 10^{-3} \mathrm{MJ}\right.$ $\left.\mathrm{kg}^{-1}{ }^{\circ} \mathrm{K}^{-1}\right), e_{\mathrm{s}}$ is saturation vapor pressure at $T_{\mathrm{a}}(\mathrm{kPa}), e_{\mathrm{a}}$ is actual vapor pressure of the air at $T_{\mathrm{a}}(=$ saturation vapor pressure at the dew point of $\left.T_{\mathrm{a}}\right), \gamma$ is the psychrometer coefficient $(\mathrm{kPa}$ $\left.{ }^{\circ} \mathrm{K}^{-1}\right), r_{\mathrm{c}}$ is canopy resistance $\left(\mathrm{s} \mathrm{m}^{2} \mathrm{~m}^{-3}\right)$ and $r_{\mathrm{a}}$ is aerodynamic boundary layer resistance to heat and water vapor diffusion $\left(\mathrm{s} \mathrm{m}^{2} \mathrm{~m}^{-3}\right)$.

Modifications of Equation 1 mainly refer to the surface area of a single twig, which has different geometric and aerodynamic properties than the surface of a single leaf (Monteith 1965, 1981) or dense vegetation (Garratt and Hicks 1973, Brutsaert 1975, Allen et al. 1989). In our modification, a twig including its laminar boundary layer is modeled as an ellipsoid with a dynamically changing surface area $Z_{\mathrm{T}}\left(\mathrm{m}^{-2}\right)$ depending on the boundary layer thickness $(\delta ; \mathrm{m})$. Consequently, the aerodynamic properties of such an object require different physical functions to be calculated and Equations 2-7 explain the modifications.

$$
\mathrm{ET}_{\mathrm{T}}=\left|\frac{\Delta\left(R_{\mathrm{n}} \chi-W\right)+\rho c_{\mathrm{p}}\left(\frac{e_{\mathrm{s}}-e_{\mathrm{a}}}{r_{\mathrm{aT}}}\right)}{\Delta+\gamma\left(1+\frac{r_{\mathrm{cT}}}{r_{\mathrm{aT}}}\right)}\right| \frac{k}{\lambda} Z_{\mathrm{T}},
$$

where $\mathrm{ET}_{\mathrm{T}}\left(\mathrm{g} \mathrm{h}^{-1}\right)$ is potential twig transpiration at a constant minimum twig resistance $r_{\mathrm{cT}}\left(\mathrm{s} \mathrm{m}^{2} \mathrm{~m}^{-3}\right), W$ is heat flux between the modeled twig and the stem $\left(\mathrm{MJ} \mathrm{m}^{-2} \mathrm{~s}^{-1}\right)$ corresponding to $G$ in Equation 1, $\chi$ takes direct solar irradiation and shaded parts of a twig into account $(\chi=0.01$ : twig completely shaded; $\chi=0.5$ : twig completely in the sun), $k$ is the conversion factor to the unit $\mathrm{g} \mathrm{h}^{-1}(k=60 \times 60 \times 1000), \lambda$ is the latent heat of vaporization of water $\left(2.45 \mathrm{MJ} \mathrm{kg}^{-1}\right)$ and $r_{\mathrm{aT}}$ is the aerodynamic boundary layer resistance for heat and water vapor transfer through the boundary layer of a twig $\left(\mathrm{s} \mathrm{m}^{2} \mathrm{~m}^{-3}\right)$. Both $Z_{\mathrm{T}}$ and $r_{\mathrm{a}}$ depend on the boundary layer thickness $\delta$. According to Böhm's (Böhm 1989, 1992) investigations on the hydrodynamics of precipitation particles, $\delta$ for an ellipsoid can be estimated from:

$$
\delta^{2}=\delta_{0}^{2} \frac{D_{\mathrm{h}}^{2}}{N_{\mathrm{Re}}} \sqrt{q}=\delta_{0}^{2} \frac{D_{\mathrm{h}} \eta_{\mathrm{a}}}{u_{\mathrm{z}} \rho} \sqrt{q},
$$

where $D_{\mathrm{h}}$ is the characteristic length of the twig presented to the air current, $N_{\mathrm{Re}}$ is the Reynolds number, $q$ is the ratio of the effective area of the twig (shadow projected in the direction of the flow) to the corresponding circumscribed area (shadow of $\left.Z_{\mathrm{T}}\right), u_{\mathrm{z}}$ is wind velocity and $\delta_{0}$ is the geometrical factor for laminar currents impinging on a curved surface $\left(\delta_{0}\right.$ between 1.9 and 2.5). Considering the aerodynamic properties of a modeled twig, $q$ can be set at approximately 0.15 (Böhm 1992). Potential variations of $q$ from twig to twig are considered in the optimized parameter $D_{\mathrm{h}}$.

When the value of $N_{\mathrm{Re}}$ is between about 2000 and 450,000, turbulent fluxes occur and a laminar boundary layer $\delta$ exists (Böhm 1991), but when $N_{\mathrm{Re}}$ exceeds 450,000, the boundary 
layer tends to become turbulent and Equation 3 is no longer applicable. The dynamic viscosity factor $\eta_{\mathrm{a}}$ (Kestin and Whitelaw 1963) is calculated as:

$$
\eta_{\mathrm{a}}=1.718+0.0049 T_{\mathrm{T}}-1.2 \times 10^{-5} \min ^{2}\left(T_{\mathrm{T}}, 0\right),
$$

where $T_{\mathrm{T}}$ is the twig surface temperature $\left({ }^{\circ} \mathrm{C}\right)$, representing the temperature of the air masses within the boundary layer. According to the physical properties of a laminar boundary layer, $r_{\mathrm{aT}}$ is calculated as:

$$
r_{\mathrm{aT}}=\frac{\delta}{k_{\mathrm{u}}}
$$

where $k_{\mathrm{u}}$ is the molecular diffusion coefficient for heat or vapor, which depends on $T_{\mathrm{T}}$ and $P\left(P_{0}=\right.$ standard air pressure $=$ $100 \mathrm{kPa})$ :

$$
k_{\mathrm{u}}=\frac{P_{0}}{P}\left(2 \times 10^{-5}+1.5 \times 10^{-7} T_{\mathrm{T}}\right) .
$$

The surface of a modeled twig with area $Z_{\mathrm{T}}$ may be viewed as an envelope over the twig, including its boundary layer. This envelope changes in surface area with the thickness of the boundary layer. An increase in $\delta$ results in a decrease in $Z_{\mathrm{T}}$ as the boundary layers of single needles are clumped into the boundary layer of the whole twig and the envelope loses some of its surface structure. The following function for $Z_{\mathrm{T}}$ is a sigmoid curve and roughly takes into account this geometric property of the modeled twig. Thus, $Z_{\mathrm{T}}$ as a function of the boundary layer thickness is modeled as:

$$
Z_{\mathrm{T}}(\delta)=Z_{\mathrm{T} 0}\left(a+\frac{b}{1+\exp (c \delta)}\right)
$$

where $a, b$ and $c$ are empirical parameters for the sigmoid curve to keep $Z_{\mathrm{T}}$ within a range of 0.7 to 1.2 times $Z_{\mathrm{T} 0}$, and $Z_{\mathrm{T} 0}$ is mean $Z_{\mathrm{T}}$ for the most frequent $\delta$.

Model parameters $Z_{\mathrm{T} 0}, r_{\mathrm{cTmin}}, \chi$ and $D_{\mathrm{h}}$ were optimized for a 15-day set of microclimate and sap flow data by a mathematical algorithm (Solver, Excel 98), which used regression itera- tion steps. In the optimizing process, we used a weighting factor of 5 for negative deviations between $\mathrm{ET}_{\mathrm{T}}$ and $F$. In this way, it was taken into account that the potential transpiration rate is never lower than the real transpiration rate and the program was forced to find a solution for which the simulated course of $\mathrm{ET}_{\mathrm{T}}$ was close to $F$ but did not, with few exceptions, fall below it. The optimized parameters and characteristic values for $\mathrm{ET}_{\mathrm{T}}$ simulations of the twigs investigated are given in Table 3.

\section{Results}

\section{Microclimatic gradients}

Gradients of temperature, humidity, wind and light occurred not only within but also between the tree crowns (Figure 1). The gradients changed during the day and were steepest at noon on clear, sunny days (data not shown). In the morning, the dark green needles of the upper crown absorbed solar radiation and raised the within-crown temperature. A temperature difference of up to $5{ }^{\circ} \mathrm{C}$ was detected between the warmest spot in the crown top and the coolest spot in the understory. In the afternoon, the local heat distribution changed entirely. The warmest points were observed between the individual tree crowns and the coolest point was found within the lower crown. The cooling effect of transpiration significantly reduced both temperature and VPD in the crowns. In the afternoon, the mid-crown air showed a significantly higher humidity and lower temperature compared with the intercrown air. The gradients diminished during the night and on cloudy days.

Other relevant microclimatic components for $\mathrm{ET}_{\mathrm{T}}$ (light and wind) showed more linear relationships with canopy height. In general, solar irradiance and wind velocity decreased from treetops toward the ground. Averaged over the whole summer, the lower crown located $8 \mathrm{~m}$ above ground received $60 \%$ of the wind and $51 \%$ of the light of the upper crown area $(18 \mathrm{~m})$.

\section{Links between local microclimate, sap flow and stomatal conductance}

To observe continuously the stomatal behavior of single twigs in a tree crown, high-resolution temporal and spatial microcli-

Table 3. Model parameters for simulating potential transpiration of twigs investigated by sap flow gauges. Abbreviations: $Z_{\mathrm{T} 0}$ is total twig surface area; $r_{\mathrm{cTmin}}$ is minimum stomatal resistance; $r_{\mathrm{aTmin}}$ and $r_{\mathrm{aTmax}}$ are the minimum and maximum aerodynamic resistances of the boundary layer, respectively; $\delta$ is boundary layer thickness; $\chi$ is a factor representing the ratio between irradiated and shaded twig parts; and $D_{\mathrm{h}}$ is characteristic length of the twig presented to the air current.

\begin{tabular}{lllllr}
\hline Twig & $\begin{array}{l}Z_{\mathrm{T} 0} \\
\left(\mathrm{~m}^{2}\right)\end{array}$ & $\begin{array}{l}r_{\mathrm{cTmin}} \\
\left(\mathrm{s} \mathrm{m}^{-1}\right)\end{array}$ & $\begin{array}{l}r_{\mathrm{aTmin}}-r_{\mathrm{aTmax}} \\
\left(\mathrm{s} \mathrm{m}^{-1}\right)\end{array}$ & $\begin{array}{l}\delta \\
(\mathrm{m})\end{array}$ & $\begin{array}{l}\chi \\
D_{\mathrm{h}} \\
(\mathrm{mm})\end{array}$ \\
\hline B.61b & 0.26 & 249 & $14-68$ & $0.0004-0.0018$ & 0.012 \\
B.62a & 0.79 & 237 & $13-63$ & $0.0003-0.0017$ & 0.138 \\
B.5a & 0.95 & 119 & $10-39$ & $0.0003-0.0011$ & 0.260 \\
B.4b & 0.85 & 170 & $9-36$ & $0.0003-0.0010$ & 0.326 \\
C.181 & 1.45 & 247 & $13-64$ & $0.0003-0.0017$ & 0.100 \\
C.182 & 1.55 & 258 & $13-67$ & $0.0004-0.0017$ & 0.070 \\
\hline
\end{tabular}




\section{Temperature profile $\left({ }^{\circ} \mathrm{C}\right)$}
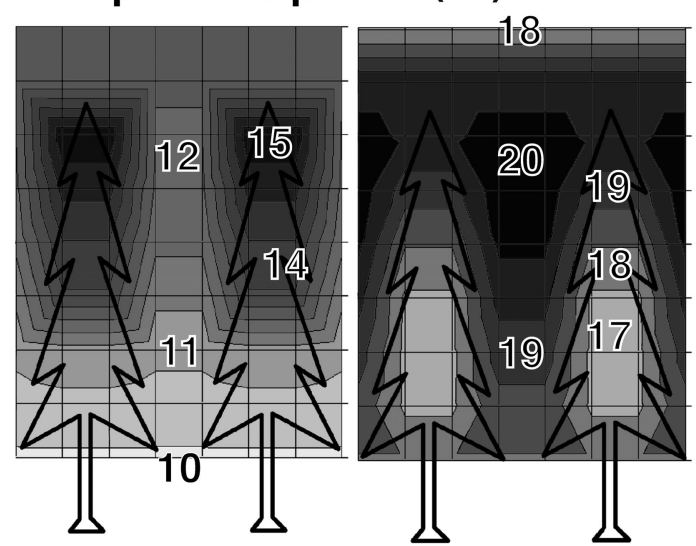

$35 \mathrm{~m}$

$25 \mathrm{~m}$

$22 \mathrm{~m}$

$20 \mathrm{~m}$

$18 \mathrm{~m}$

$14 \mathrm{~m}$

$10 \mathrm{~m}$

$6 \mathrm{~m}$

$2 \mathrm{~m}$

$0 \mathrm{~m}$

Humidity profile (\%)

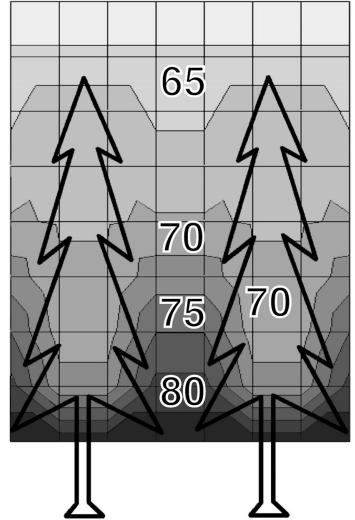

$10 \mathrm{~h}$

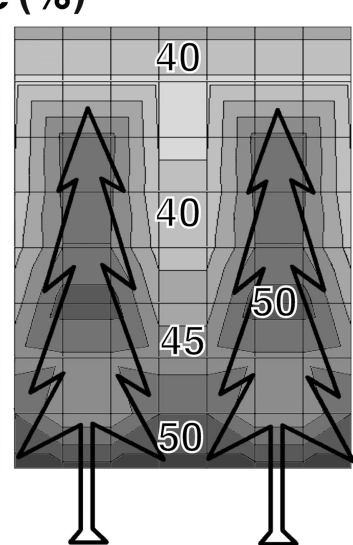

$14 \mathrm{~h}$
$35 \mathrm{~m}$

$25 \mathrm{~m}$

$22 \mathrm{~m}$

$20 \mathrm{~m}$

$18 \mathrm{~m}$

$14 \mathrm{~m}$

$10 \mathrm{~m}$

$6 \mathrm{~m}$

$2 \mathrm{~m}$

$0 \mathrm{~m}$

Figure 1. Temperature and humidity conditions on the southeast side of a Norway spruce crown at 1000 and $1400 \mathrm{~h}$ on a sunny day. The contour plots were derived by interpolating the data of two profiles: one measured in the tree crown and one measured on a tower between the trees.

mate data were used to calculate potential $\mathrm{ET}_{\mathrm{T}}$ (Equation 2), which was then compared with measured $F$. Diurnal patterns of $F, g_{\mathrm{s}}$ and microclimatic data are presented for the upper and lower crown to highlight the differences in stomatal behavior between the two locations. Figure 2 gives an example for a representative 10-day period. On cloudy days, $\mathrm{ET}_{\mathrm{T}}$ and $F$ strongly coincided, confirming that Equation 2 produced reasonable potential transpiration rates of twigs under conditions of maximally opened stomata. Even small changes in $\mathrm{ET}_{\mathrm{T}}$ were paralleled by changes in $F$. Small errors in the simulation were observed only on days with very high transpiration peaks (e.g., twig B.5a on July 25). Periods in which $F$ remained less than $\mathrm{ET}_{\mathrm{T}}$ indicated a reduction in $g_{\mathrm{s}}$. Days with midday stomatal closure were identified by the sudden drop in $g_{\mathrm{s}}$ around noon, despite increasing $\mathrm{ET}_{\mathrm{T}}$ (e.g., July 19-22 and July 25-26 in Figure 2). Although the soil remained permanently wet during the whole summer (data not shown), it did not prevent stomatal closure. Midday stomatal closure occurred on most clear days between July and September. Ef- fects of gradients in microclimate within a crown were observed when the respective courses of $\mathrm{ET}_{\mathrm{T}}$ in the upper and the lower crown were compared. For instance, on a sunny morning after a rainy night, the steep increase in $\mathrm{ET}_{\mathrm{T}}$ occurred much earlier in the upper crown than in the lower crown where VPD and temperature remained low because of shading by the surrounding vegetation. Although differences in $\mathrm{ET}_{\mathrm{T}}$ determined sap flow rates in twigs in both the upper $\left(F_{\mathrm{u}}\right)$ and lower part $\left(F_{1}\right)$ of the crown, the courses of $F_{\mathrm{u}}$ and $F_{1}$ sometimes differed dramatically. Particularly on days with midday stomatal closure, the courses of $F_{\mathrm{u}}$ and $F_{1}$ varied much more than could be explained by differences in microclimate and corresponding $\mathrm{ET}_{\mathrm{T}}$.

\section{Initial conditions for midday stomatal closure}

Because midday stomatal closure was accompanied by a sudden, rapid decrease in $g_{\mathrm{s}}$, we examined the effects of microclimatic and physiological conditions on $g_{\mathrm{s}}$ in an attempt to identify the mechanisms triggering the closure process. Relationships between VPD and $g_{\mathrm{s}}$, and between $F$ and $g_{\text {s }}$ are shown in Figure 3, together with the range of values prevailing at the time of initial stomatal closure. For VPD values within or above this range, the correlation between VPD and $g_{\mathrm{s}}$ was negative, indicating active stomatal closure. The correlation between $F$ and $g_{\text {s }}$ gave no insight into stomatal behavior, because $g_{\text {s }}$ paralleled $F$. A more detailed characterization of the initial conditions for midday stomatal closure is summarized in Figure 4. Microclimatic conditions at the onset of midday stomatal closure were consistent throughout the canopy, although these conditions were reached in the upper-crown twigs on average $1 \mathrm{~h}$ before they were reached in the lowercanopy. Values of VPD, $\mathrm{ET}_{\mathrm{T}}$ and $T_{\mathrm{T}}$ remained within a small range at the time of initial closure throughout the summer. A significant difference in microclimatic conditions between the upper and lower crown was found only for solar irradiance (Figure 5).

There was a qualitatively large difference in $F$ in the two parts of the crown. At the time of initial stomatal closure, $F_{\mathrm{u}}$ was close to the maximum flow rate (Figure 2), whereas $F_{1}$ was at about $65 \%$ of maximum. The timing of initial midday stomatal closure could be explained by a VPD model with an average precision of $60 \pm 30 \mathrm{~min}( \pm \mathrm{SE}$ for independent measurements) for both upper- and lower-crown twigs assuming stomatal closure at a VPD of $1.25 \mathrm{kPa}$. With an $\mathrm{ET}_{\mathrm{T}}$ model, the initial time of midday stomatal closure in upper-crown twigs was simulated with a precision of $35 \pm 34 \mathrm{~min}$, but this method was unsuccessful for lower-crown twigs (precision: $117 \pm$ $38 \mathrm{~min}$ ). The lower-crown twigs often had lower $F_{1}$ and $\mathrm{ET}_{\mathrm{T}}$ at the time of initial stomatal closure (e.g., July 20 and 21 in Figure 2).

\section{Different stomatal behavior in twigs of the upper and lower crown after the initial closure}

In contrast to the consistent initial microclimatic conditions for midday stomatal closure within the entire canopy (Figure 4), the time course of $g_{\mathrm{s}}$ in upper-crown twigs following 


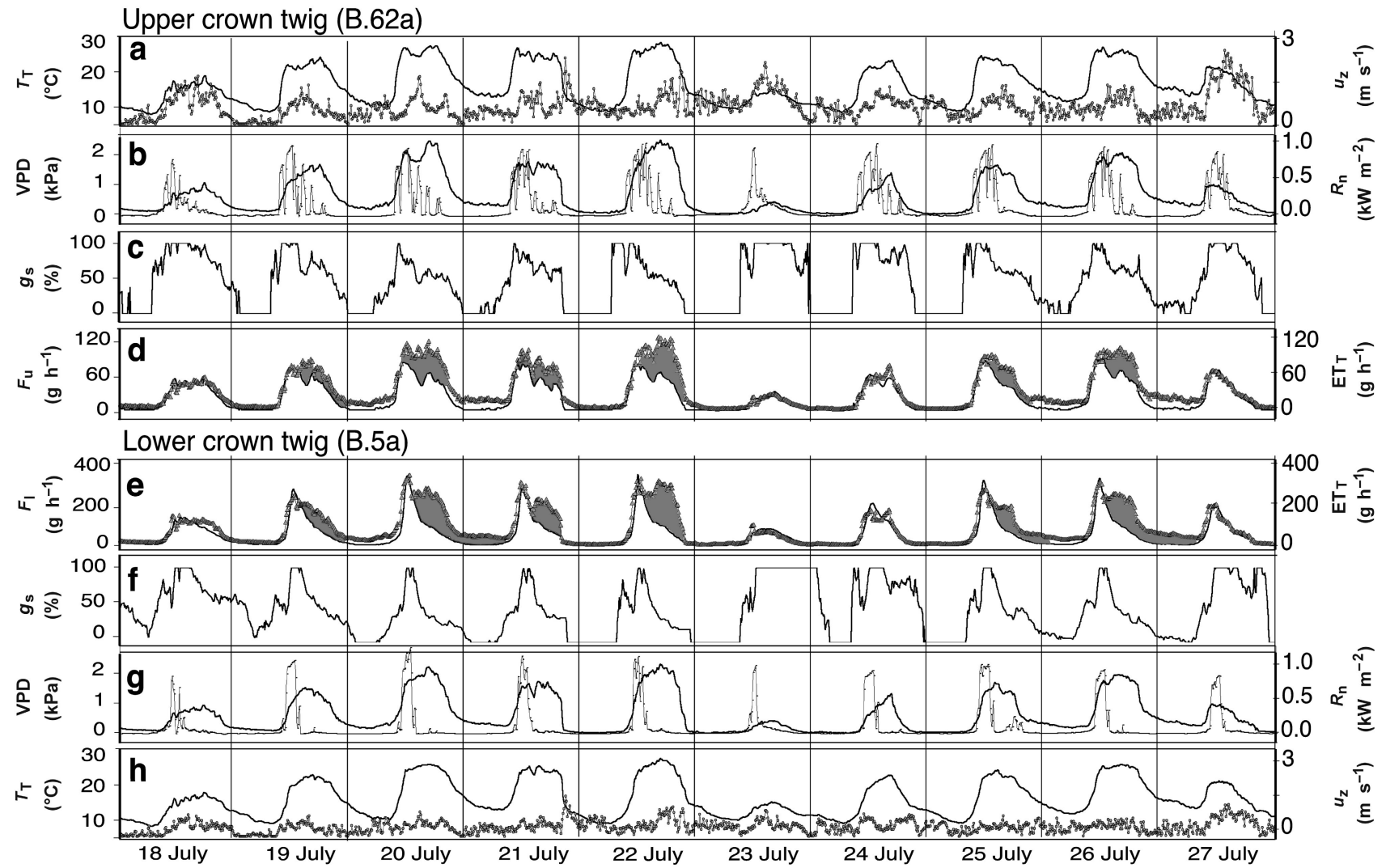

Figure 2. Microclimate and transpiration of two twigs in a mature P. abies tree (a-d): Twig B.62a in the upper crown (18 m); and (e-h): Twig B.5a in the lower crown $(8 \mathrm{~m})$. Air temperature $\left(T_{\mathrm{T}}\right.$; solid line) and wind velocity $\left(u_{\mathrm{z}}\right.$; circles) in (a) and $(\mathrm{h}), \mathrm{VPD}\left(\operatorname{solid}\right.$ line) and radiation $\left(R_{\mathrm{n}}\right.$; thin line with dots) in (b) and (g), relative stomatal twig conductance $\left(g_{\mathrm{s}}\right)$ in $(\mathrm{c})$ and (f), and sap flow $(F$; solid line) and potential transpiration (ET ; triangles) in (d) and (e) are shown for 10 days in July 1995. Periods of reduced $g_{\mathrm{s}}$ because of midday stomatal closure are shaded in (d) and (e).

the initial closure event differed from that in lower-crown twigs. After reaching the conditions for initial stomatal closure, upper-canopy twigs maintained transpiration at a relatively high rate by continuous stomatal opening and closing. In contrast, transpiration in the lower-canopy twigs rapidly decreased to, and remained at, a low rate. Stomata in lower-canopy twigs did not reopen for the rest of the day, e.g., July 26 in Figure 2: $F_{1}$ dropped rapidly to about $30 \%$ of potential $\mathrm{ET}_{\mathrm{T}}$, and an increase in $\mathrm{ET}_{\mathrm{T}}$ at $1330 \mathrm{~h}$ had absolutely no effect on flow rate. In contrast, $F_{\mathrm{u}}$ also dropped after the initial stomatal closure, but only to about $65 \%$ of $\mathrm{ET}_{\mathrm{T}}$. At about $1500 \mathrm{~h}, g_{\mathrm{s}}$ and $F_{\mathrm{u}}$ increased again, and sap flow rate was then maintained at a relatively high rate. In general, $g_{\mathrm{s}}$ in upper-crown twigs decreased to $70 \%$ during the $4 \mathrm{~h}$ following the initial closure, whereas $g_{\mathrm{s}}$ in lower-crown twigs, on average, dropped to $50 \%$.

The relationship between needle dry mass $\left(w_{\mathrm{N}}\right)$ and hydraulic twig properties did not explain the different stomatal responses in the upper and lower parts of the crown (Figure 6). As expected, $w_{\mathrm{N}}$ was closely related to $Z_{\mathrm{T} 0}$, but was unrelated to $r_{\mathrm{cTmin}}$ or $k_{\mathrm{T}}$. Comparisons between lower-crown and uppercrown twigs showed that they had similar hydraulic properties. However, $r_{\mathrm{cTmin}}$ appeared smaller in lower-crown twigs than in upper-crown twigs (Figure 6c) but this difference did not ex- plain the more persistent closure reaction of the stomata in the lower-crown twigs.

\section{Discussion}

In mature subalpine P. abies, the microclimatic conditions initiating midday stomatal closure were similar for needles of twigs at all heights in the tree crown; however, the stomata reacted differently after the initial closure depending on their position in the crown. The timing of the initial midday stomatal closure was explained to a large extent by VPD and, for the upper-crown twigs, $\mathrm{ET}_{\mathrm{T}}$, because both factors occurred within a small range of values at this time. Nevertheless, microclimate alone cannot pinpoint the exact timing of stomatal closure or explain subsequent stomatal behavior. The explanation of the difference in stomatal reaction after initial closure between upper- and lower-crown twigs is complex and may involve coupling of a number of internal and external factors through a network of feedback and feed forward cycles.

\section{Methodological reflections}

The essential requirements for a functional interpretation of stomatal behavior are the local microclimatic conditions at the 
Upper Crown (B62.a)

a

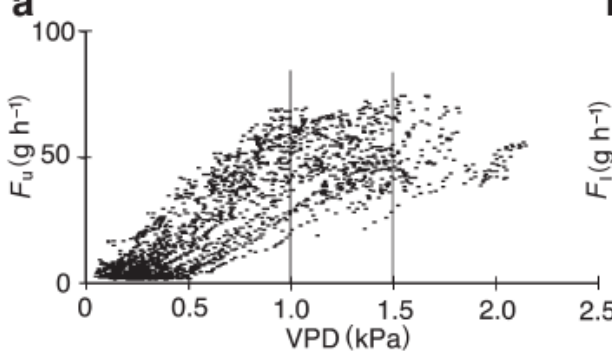

C
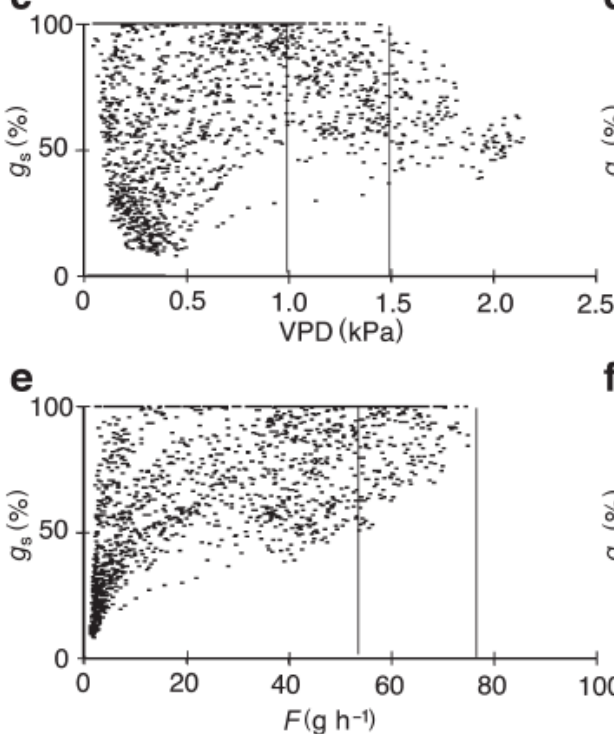

Lower Crown (B5.a)

b

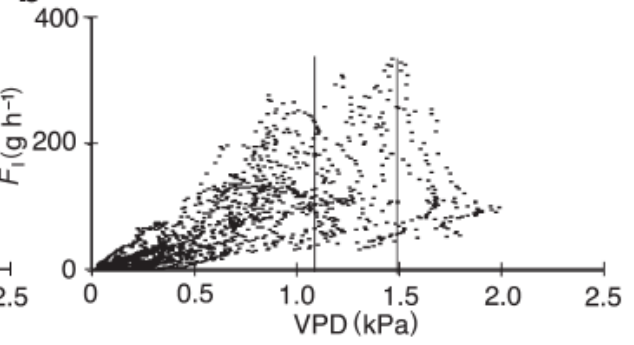

d

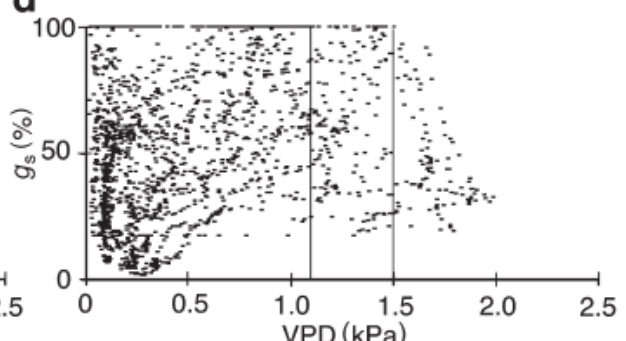

f

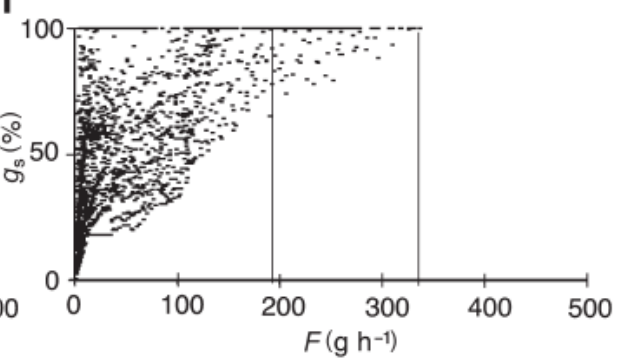

Figure 3. Relationship between vapor pressure deficit (VPD), sap flow $(F)$ and stomatal conductance $\left(g_{\mathrm{s}}\right)$ of Twig B.62a in the upper crown (a, c and d) and Twig B.5a in the lower crown (b, $d$ and $f$ ). The area enclosed by the two vertical lines depicts the range in which initial stomatal closure was observed. transpiring surface (Monteith 1981, Dolman et al. 1991, Meinzer and Grantz 1991) and water flux rates, which are minimally affected by capacitance delays because of the use of stored water in the tree. We extrapolated microclimatic conditions measured with high spatial and temporal resolution at single points on the twig surface to the entire twig surface. This was achieved with a model that simulated a dynamically changing twig surface depending on $\delta$, based on the PenmanMonteith equation for evapotranspiration (Penman 1948, Monteith 1965). The individual ratios of shaded twig parts to twig parts exposed to sunlight were taken into account, as well as the relative proportion of $Z_{\mathrm{T}}$ that was exposed to the air current. The close correspondence between measured $F$ and simulated $\mathrm{ET}_{\mathrm{T}}$ on cloudy days ( $g_{\mathrm{s}}$ was assumed to be maximal) (a) Upper twigs

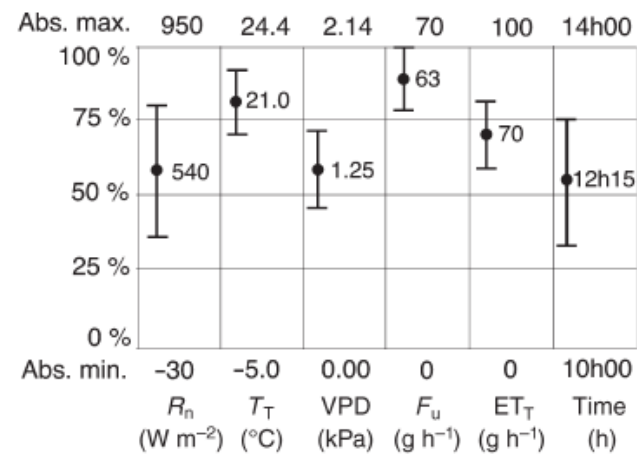

\section{(b) Lower twigs}

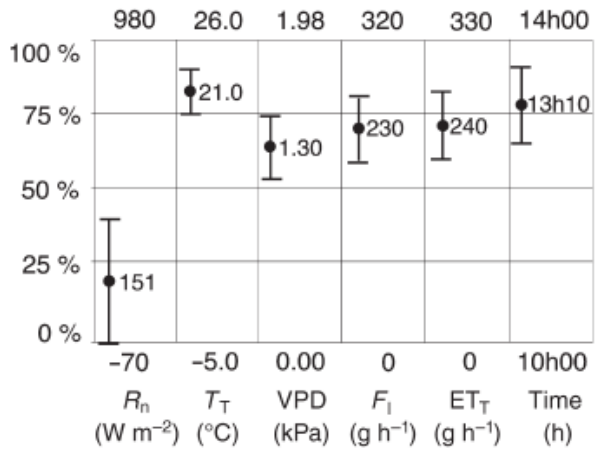

Figure 4. Time and local conditions at initial stomatal closure in upper-crown (a) and lower-crown twigs (b) of Tree B. Mean values and deviations (calculated as for the standard deviation for independent measurements) are depicted in relation to the absolute maximum (Abs. max.) and minimum (Abs. min.) values over the summer of 1995. Abbreviations: $T_{\mathrm{T}}=$ temperature at twig surface; VPD = vapor

pressure deficit; $R_{\mathrm{n}}=$ radiation; $\mathrm{ET}_{\mathrm{T}}=$ evapotranspiration; $F_{1}=$ sap flow per twig in the lower crown; and $F_{\mathrm{u}}=$ sap flow per twig in the upper crown. (Note: The upper-crown twigs were significantly smaller than the lower-crown twigs and therefore $F_{\mathrm{u}}$ values were smaller than $F_{1}$ values. For comparisons, we used respective performance in percentages.) 


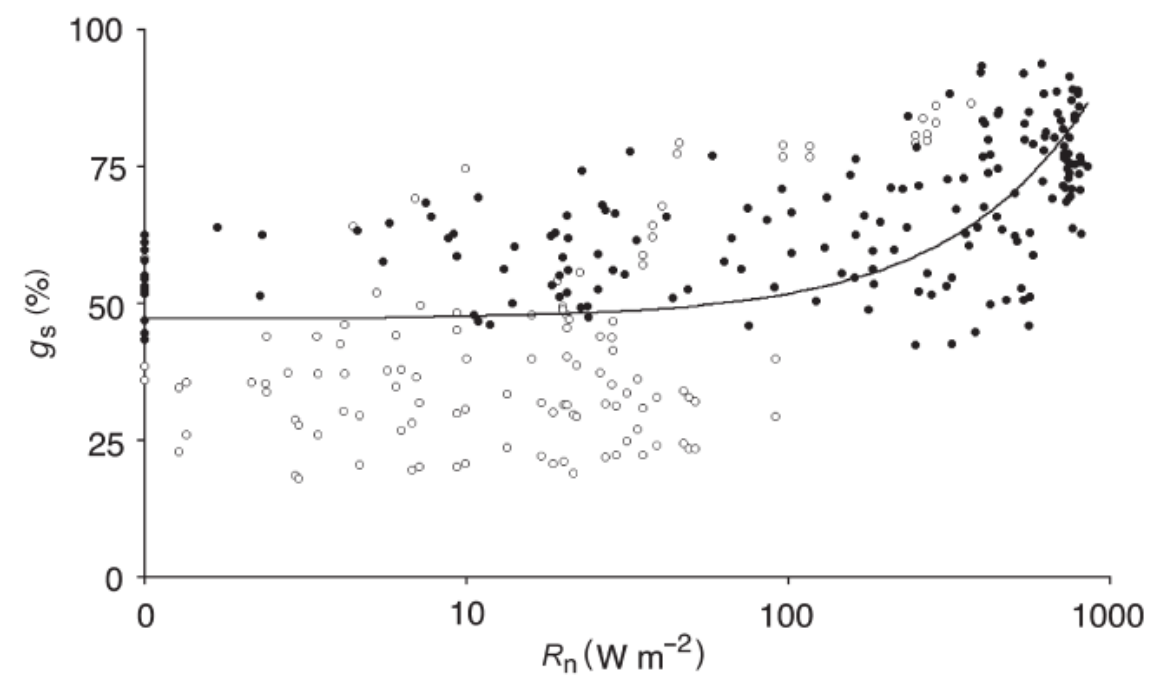

Figure 5. Relationship between solar radiation $\left(R_{\mathrm{n}}\right)$ and stomatal conductance $\left(g_{\mathrm{s}}\right)$ for time periods with $\mathrm{ET}_{\mathrm{T}}$ $>80 \%$ of the maximum observed value after initial midday stomatal closure. Symbols: $\mathrm{O}=$ upper-crown twigs and = lower-crown twigs. was evidence of the success of this approach. In our study, sap flow measurements on twigs were affected by capacitance delays: $F$ lagged $\mathrm{ET}_{\mathrm{T}}$, especially in the morning (Figure 2) when internal water reserves depleted rapidly (Zweifel et al. 2000, Zweifel and Häsler 2001). However, this approach minimized error due to the use of inappropriate meteorological data and delayed sap flow rates. It also circumvented decoupling effects (Jarvis and McNaughton 1986, Meinzer et al. 1997, Wullschleger et al. 1998) by integrating the coupling between leaves and the atmosphere into the twig evaporation model with the direct calculation of $\delta$, from locally measured microclimatic conditions.

\section{Time of initial stomatal closure}

It was possible to predict the timing of midday stomatal closure with a precision of $60 \pm 30 \mathrm{~min}$ on average for both upperand lower-crown twigs with a simple VPD model, which assumed stomatal closure was initiated at a VPD of $1.25 \mathrm{kPa}$. There was no general improvement in precision in predicting stomatal closure with an $\mathrm{ET}_{\mathrm{T}}$ model with twig-specific threshold values.

These results imply that VPD is as useful as $\mathrm{ET}_{\mathrm{T}}$ in explaining the time of initial stomatal closure. These empirical findings are difficult to interpret in mechanistic terms because there is no plausible physiological mechanism for sensing
VPD. However, Monteith (1995) and Dewar (1995) argue that VPD is one of the driving forces for transpiration, and that it is the rate of transpiration that is sensed, not VPD. Dewar (1995) proposed a theoretical mechanism of how transpiration rates could be sensed physiologically via changes in the gradient of total water potential between guard cells and epidermal cells. Furthermore, Monteith (1995) argued that for most plants, $g_{\mathrm{s}}$ decreases linearly with increasing transpiration rate. However, this relationship was not observed in our data set (Figure 3), which is more consistent with the conclusions of Bunce (1996) that high transpiration rates do not control stomatal response to VPD. We found a pronounced threshold value of VPD, beyond which $g_{\mathrm{s}}$ decreased rapidly. Similar findings have been presented by Meinzer et al. (1996), Bond and Kavanagh (1999) and Hogg et al. (2000).

Bond and Kavanagh (1999) suggested a model to bring the VPD sensitivity of stomata into a physiological context. Their model assumes that stomatal behavior is dependent on the water supply capacity of the vascular system, and that stomata regulate transpirational water flux to prevent xylem water potential from falling below a threshold value (Jones and Sutherland 1991). Thus, stomatal response to humidity and soil water availability can be explained by two parameters: leaf-specific hydraulic conductance and threshold leaf water potential. We tested this approach based on the following key data for a

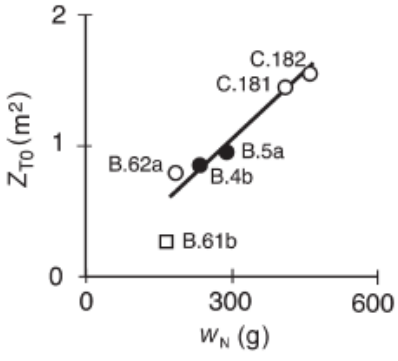

b

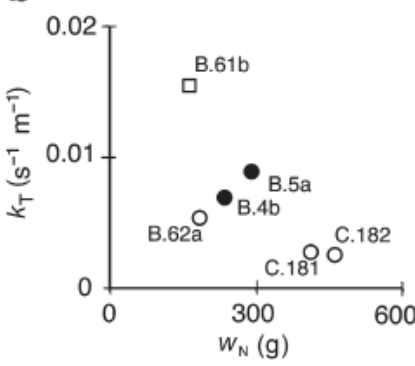

C

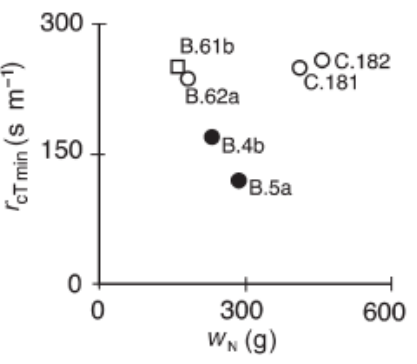

Figure 6. Relationship between needle dry mass $\left(w_{\mathrm{N}}\right)$ of the six twigs investigated and (a) twig surface $\left(\mathrm{Z}_{\mathrm{T} 0}\right)$, (b) specific twig conductance $\left(k_{\mathrm{T}}\right)$ and (c) minimum stomatal resistance $\left(r_{\mathrm{c} T \min }\right)$. Symbols: $\mathrm{O}=$ upper-crown twigs and - = lower-crown twigs. Twig B.61b ( $\square$ ) was almost entirely in the shade of other twigs and therefore represents a special situation. 


\section{(a) Twig 62.a (18m)}

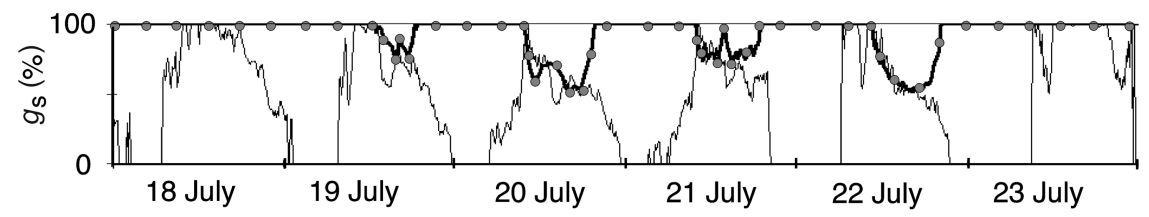

(b) Twig 5.a (8m)

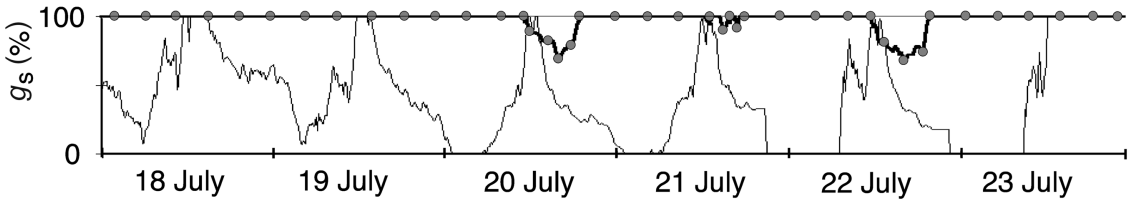

Figure 7. Measured (thin line) and modeled (bold line with circles) course of stomatal conductance $\left(g_{\mathrm{s}}\right)$ in (a) an upper-crown twig and (b) a lowercrown twig. Modeled $g_{\mathrm{s}}$ was calculated as proposed by Bond and Kavanagh (1999).
P. abies. (It is known from Lu et al. $(1995,1996)$ and Zweifel et al. (2000) that the threshold water potential is within the range of $-2.3 \pm 0.3 \mathrm{MPa}$ and that xylem water potential rarely drops below this value (Sellin 1998).) We therefore assumed a constant hydraulic conductance for our trees and used measured needle water potentials (data not shown) to simulate the diurnal course of water potentials with an empirical function. Figure 7 shows that the timing of initial stomatal closure is simulated well by the model of Bond and Kavanagh (1999) even though simulation of the diurnal time course of $g_{\mathrm{s}}$ was poor. In particular, it was the simulation of the lower-crown twigs that failed.

\section{Time course of $g_{s}$ after the initial closure event}

We consistently observed differences in stomatal behavior between upper- and lower-crown twigs after initial closure. Canopy layer-dependent diurnal courses of $g_{\mathrm{s}}$ have been reported by Dolman et al. (1991) and Williams et al. (1996) based on measurements in a tropical rainforest and a model prediction, respectively. However, these authors related the variations in stomatal response mainly to differences in microclimate within the canopy, whereas we conclude that both microclimate and internal factors differ within a canopy and that stomatal responses after the initial closure event reflect these differences in evaporative conditions.

Given the difficulties of simulating the timing of initial stomatal closure, there is little chance than we can successfully model the subsequent course of $g_{\mathrm{s}}$ with a simple relationship between leaf water potential and microclimate, because stomatal behavior after the initial closure seemed to respond inconsistently to microclimate within the same tree crown. The empirical finding of Meinzer and Grantz (1991) that stomatal and boundary layer conductance in series $\left(r_{\mathrm{cT}}+r_{\mathrm{aT}}\right)$ are constant could not be confirmed. The increase in $r_{\mathrm{cT}}$ during midday stomatal closure was never compensated by a decrease in $r_{\text {aT }}$. As depicted in Figure 7, the model of Bond and Kavanagh (1999) predicts a reopening of the stomata to a maximum $g_{\mathrm{s}}$ as soon as leaf water potential becomes higher than the threshold water potential. Our measurements show a much more distinctive and longer reduction in $g_{\mathrm{s}}$, particularly in the lower crown. We therefore hypothesize that stomatal conductance is not only actively down-regulated by inhibitory factors such as lowered water potentials or increased concentrations of a biochemical messenger but is also actively up-regulated by stimulatory factors, such as light (Mohr and Schopfer 1995). A model including light as an accelerating factor could also reduce the discrepancy observed between simulated and measured $g_{\mathrm{s}}$ during the nighttime. Measurements indicate closed stomata during the night, whereas models estimate a high $g_{\mathrm{s}}$. Although this nighttime transpiration generates only a relatively small error in estimates of absolute amounts of water transpired by tree crowns, from a physiological point of view it

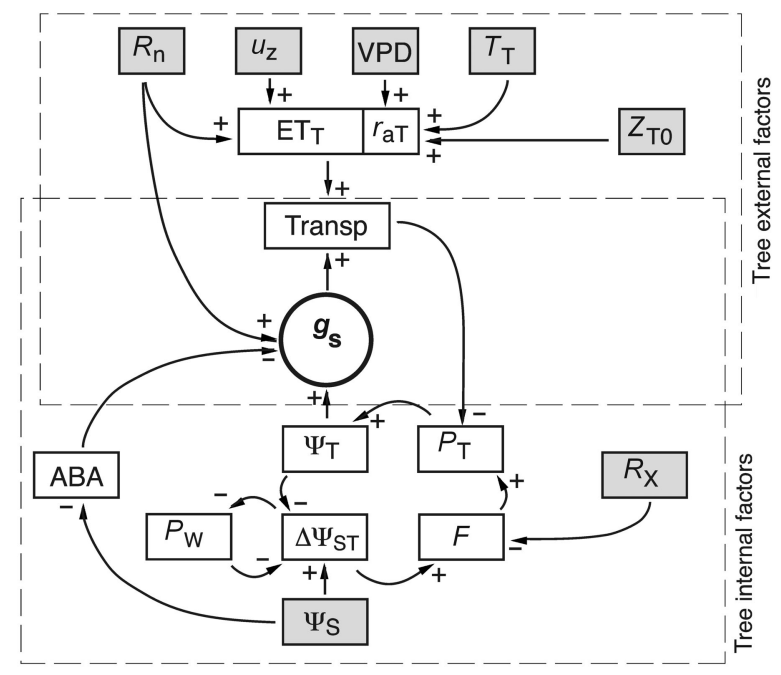

Figure 8. Proposed regulatory system modeling stomatal conductance $\left(g_{\mathrm{s}}\right)$ in response to external and internal factors. Abbreviations: $T_{\mathrm{T}}=$ temperature at twig surface; $\mathrm{VPD}=$ vapor pressure deficit; $R_{\mathrm{n}}=$ radiation; $u_{\mathrm{z}}=$ wind velocity; $Z_{\mathrm{T} 0}=$ twig surface area; $\mathrm{ET}_{\mathrm{T}}=$ evapotranspiration; Transp = twig transpiration; $F=$ sap flow in the twig; $P_{\mathrm{T}}=$ water saturation of the twig; $P_{\mathrm{W}}=$ water saturation of the tree; $\Psi_{\mathrm{T}}=$ twig water potential; $\Psi_{\mathrm{S}}=$ soil water potential; $\Delta \Psi_{\mathrm{ST}}=$ water potential gradient between soil and twig; $\mathrm{ABA}=$ concentration of an inhibiting messenger molecule; and $R_{\mathrm{X}}=$ hydraulic flow resistance between soil and twig. The arrows with the symbols + or - indicate positive and negative interdependence, respectively, between system components 1 and 2. Input factors are located in shaded boxes, dynamic system components are located in open boxes or circles. 
shows that stomatal behavior is not well described by such an approach.

\section{Suggested conceptual model for stomatal regulation}

Because of the inability of the $g_{\mathrm{s}}$ models to simulate accurately the observed variations in stomatal behavior within a canopy, we have developed a new system of interactions between the components involved to explain the phenomenon. The suggested stomatal regulatory system (Figure 8) is based on the model of Bond and Kavanagh (1999) and Meinzer and Grantz (1991), and additionally includes the direct effect of light for reopening stomata after closure and the indirect effect of the water status of both the twig and the whole tree. Integrating this concept into a hydraulic flow and storage system (Zweifel et al. 2001), we simulated the course of $g_{\mathrm{s}}$ with microclimatic conditions (air and soil) as the only inputs. With this model, we achieved a more precise initial timing of midday stomatal closure and a mechanistic explanation for the different stomatal responses under similar microclimatic conditions of twigs in the upper and lower crown.

In our model, stomata exclusively respond to twig water potential $\left(\Psi_{\mathrm{T}}\right)$, a biochemical messenger and light. All other system components have only an indirect effect on $g_{\text {s }}$ (Figure 8). Needle water potential, as a directly sensed factor, is plausible because stomatal guard cells are sensitive to pressure changes (Raschke 1979, Dewar 1995). Decreasing water potentials parallel decreases in cell water content and dehydration of guard cells, and are assumed to be the main reason for closed stomata (Hensel 1993). A biochemical messenger can directly bind to a membrane protein and therefore determine release of ions that change the osmotic potential and thus influence the turgor of a cell compartment (Schroeder and Hedrich 1989), leading to a similar effect as described in response to changes in water potential. Even if this feed forward mechanism is unnecessary to explain the phenomenon in the present investigation, this mechanism seems important because numerous investigations have reported stomatal closure despite leaf water potentials far above the threshold value (Gowing et al. 1990, Khalil and Grace 1993, Shashidhar et al. 1996).

From molecular research on photomorphogenesis it is known that blue-light and white-light photoreceptors play a role in stomatal responses to light (Taiz and Zeiger 1998). Blue and white light promote stomatal opening, whereas red light induces stomatal closure (Lascève et al. 1999). If we assume a direct up-regulating effect of light, low solar irradiance provides an explanation for the failure of stomata in lower-crown twigs to reopen after midday stomatal closure (Figure 5). The assumption of a direct effect of light on the stomatal response provides a simpler and more plausible explanation of our findings compared with a mechanism based on an optimizing function for photosynthesis in response to internal $\mathrm{CO}_{2}$ concentration and light conditions (Dolman et al. 1991, Leuning et al. 1995, Williams et al. 1996).

The suggested stomatal response model (Figure 8) includes internal and external factors regulating stomatal conductance. Microclimatic conditions act as a driving force for transpiration. The transpired water reduces twig water content and thus reduces $\Psi_{\mathrm{T}}$. Stomata close when $\Psi_{\mathrm{T}}$ reaches a threshold value. This negative feedback cycle interacts with tree internal dynamics, which are determined by a positive and a negative feedback cycle and the hydraulic properties of the flow and storage system. The water flux from the soil to the crown is accelerated by the water potential gradient between these two poles and down-regulated by internal water storage depletions (Tyree 1988, Zweifel and Häsler 2001). The amount of water stored in the elastic tissue of the bark along the stem and branches is not large, but this water is depleted every day and buffers high flow rates of water (Edwards et al. 1986). In contrast to bark storage, the water from needles contributes a quantitatively important amount to daily transpiration (Tyree and Yang 1990, Hinckley et al. 1991). A mechanistic flow and storage model by Zweifel et al. (2001) has shown that this storage depletion flattens the gradients within the flow path and that there is a strong relationship between the degree of storage depletion and water potential. When this storage effect on the water potential gradient is integrated into the regulatory mechanism of $g_{\mathrm{s}}$, an increase in evaporative demand of the air leads to more rapid and steeper local gradients when internal water reserves are depleted than when internal water reserves are saturated. Thus, a short peak of transpiration generates a threshold condition in a twig when internal water storage is depleted, whereas the same microclimatic input when internal water reserves are saturated does not generate a threshold condition. If we assume, in accordance with the model of Bond and Kavanagh (1999), that a threshold leaf water potential triggers stomatal closure, the integration of a storage effect can explain the variations in stomatal reactions under similar microclimatic conditions.

\section{Conclusions}

Stomatal regulation of transpiration is a complex response of a tree to its external and internal conditions. All of the water in a tree, except what is chemically bound, is part of a single flow and storage system, which means that every regulatory step has both local and whole-tree relevance. To avoid confusion about interpretations of stomatal behavior, it is essential to distinguish between investigations on stand reactions to weather conditions and studies focusing on the physiological driving mechanisms of stomatal behavior when considering local microclimate. The physiological basis of stomatal regulation seems to be comprehensible only when microclimatic factors and the physiology of single twigs are considered in relation to the large-scale flow and storage architecture of the entire tree.

\section{Acknowledgments}

We thank R. Thum, R. Süess and A. Kölliker for their generous technical support. We are indebted to the Swiss Federal Office of Environment, Forests and Landscape (BUWAL) for the use of the infrastructure at the research site Seehornwald, Davos. We thank Prof. D.M. Newbery for critical comments on the manuscript and Ms. E.J. Sayer for editing the text. 


\section{References}

Allen, R.G., M.E. Jensen, J.L. Wright and R.D. Burman. 1989. Operational estimates of reference evapotranspiration. Agron. J. 81: 650-662.

Alsheimer, M., B. Köstner, E. Falge and J.D. Tenhunen. 1998. Temporal and spatial variation in transpiration of Norway spruce stands within a forested catchment of the Fichtelgebirge, Germany. Ann. Sci. For. 55:103-123.

Beyschlag, W., F. Kresse, R.J. Ryel and H. Pfanz. 1994. Stomatal patchiness in conifers: experiments with Picea abies (L.) Karst. and Abies alba Mill. Trees 8:132-138.

Böhm, J.P. 1989. A general equation for the terminal fall speed of solid hydrometeors. J. Atmos. Sci. 46:2419-2427.

Böhm, J.P. 1991. Review of flow characteristics and kinematics of hydrometeors in free fall. Atmos. Res. 26:285-302.

Böhm, J.P. 1992. A general hydrodynamic theory for mixed-phase microphysics. I. Drag and fall speed of hydrometeors. Atmos. Res. 27:253-274.

Bond, B.J. and K.L. Kavanagh. 1999. Stomatal behavior of four woody species in relation to leaf-specific hydraulic conductance and threshold water potential. Tree Physiol. 19:503-510.

Brutsaert, W.H. 1975. Comments on surface roughness parameters and the height of dense vegetation. J. Meteorol. Soc. Jpn. 53: 96-97.

Bunce, J.A. 1996. Does transpiration control stomatal responses to water vapour pressure deficit? Plant Cell Environ. 19:131-135.

Dewar, R.C. 1995. Interpretation of an empirical model for stomatal conductance in terms of guard cell function. Plant Cell Environ. 18:365-372.

Dolman, A.J., J.H.C. Gash, J. Roberts and W.J. Shuttleworth. 1991. Stomatal and surface conductance of tropical rainforest. Agric. For. Meteorol. 54:303-318.

Edwards, W.R.N., P.G. Jarvis, J.J. Landsberg and H. Talbot. 1986. A dynamic model for studying flow of water in single trees. Tree Physiol. 1:309-324.

Garratt, J.R. and B.B. Hicks. 1973. Momentum, heat and water vapour transfer to and from natural and artificial surfaces. Q. J. R. Meteorol. Soc. 99:680-687.

Gowing, D.J.G., W.J. Davies and H.G. Jones. 1990. A positive root-sourced signal as an indicator of soil drying in apple, Malus $\times$ domestica Borkh. J. Exp. Bot. 41:1535-1540.

Häsler, R. 1992. Long-term gas exchange measurements in a mature Picea abies of a subalpine forest. In Protection and Management of Mountain Forests. Eds. Y. Yupo and J. Zhang. Science Press, Beijing, pp 162-169.

Häsler, R., C. Savi and K. Herzog. 1991. Photosynthese und stomatäre Leitfähigkeit unter dem Einfluss von Witterung und Luftschadstoffen. In Luftschadstoffe und Wald, Bd. 5, Ergebnisse aus dem Nationalen Forschungsprogramm 14. Ed. M. Stark. Verlag Fachvereine, Zürich, pp 143-168.

Hensel, W. 1993. Pflanzen in Aktion, Krümmen, Klappen, Schleudern. Spektrum Akademischer Verlag, Heidelberg, 304 p.

Herzog, K.M. 1995. Water relations of a mature subalpine Norway spruce (Picea abies (L.) Karst.). Diss. ETH Zürich No. 11126, $86 \mathrm{p}$.

Herzog, K.M., R. Thum, G. Kronfuss, H.J. Heldstab and R. Häsler. 1998. Patterns and mechanisms of transpiration in a large subalpine Norway spruce (Picea abies (L.) Karst.). Ecol. Res. 13:105-116.

Herzog, K.M., R. Thum, R. Zweifel and R. Häsler. 1997. Heat balance measurements: to quantify sap flow in thin stems only? Agric. For. Meteorol. 83:75-94.
Hinckley, T.M., H. Richter and P.J. Schulte. 1991. Water relations. In Physiology of Trees. Ed. A.S. Raghavendra. John Wiley, New York, pp 137-162.

Hogg, E.H., B. Saugier, J.-Y. Pontailler, T.A. Black, W. Chen, P.A. Hurdle and A. Wu. 2000. Response of trembling aspen and hazelnut to vapor pressure deficit in a boreal deciduous forest. Tree Physiol. 20:725-734.

Irvine, J., M.P. Perks, F. Magnani and J. Grace. 1998. The response of Pinus sylvestris to drought: stomatal control of transpiration and hydraulic conductance. Tree Physiol. 18:393-402.

Jackson, G.E., J. Irvine and J. Grace. 1995. Xylem cavitation in two mature Scots pine forests growing in a wet and a dry area of Britain. Plant Cell Environ. 18:1411-1418.

Jarvis, P.G. and K.G. McNaughton. 1986. Stomatal control of transpiration: scaling up from leaf to region. Adv. Ecol. Res. 15:1-19.

Johnson, I.R., J.J. Melkonian, J.H.M. Thornley and S.J. Riha. 1991. A model of water flow through plants incorporating shoot/root 'message' control of stomatal conductance. Plant Cell Environ. 14: $531-544$.

Jones, H.G. and R.A. Sutherland. 1991. Stomatal control of xylem embolism. Plant Cell Environ. 14:607-612.

Kestin, J. and J.H. Whitelaw. 1963. Measurements of the viscosity of dry and humid air. Proc. Int. Symp. Humidity Moisture, Washington, pp 301-314.

Khalil, A.A.M. and J. Grace. 1993. Does xylem sap ABA control the stomatal behaviour of water-stressed Sycamore (Acer pseudoplatanus L.) seedlings? J. Exp. Bot. 44:1127-1134.

Lascève, G., J. Leymarie, M.A. Olney, E. Liscum, J.M. Christie, A. Vavasseur and W.R. Briggs. 1999. Arabidopsis contains at least four independent blue-light-activated signal transduction pathways. Plant Physiol. 120:605-614.

Leuning, R., F.M. Kelliher, D.G.G. Depury and E.-D. Schulze. 1995. Leaf nitrogen, photosynthesis, conductance and transpiration: scaling from leaves to canopies. Plant Cell Environ. 18:1183-1200.

Loustau, D., P. Berbigier, P. Roumagnac, C. Arrude-Pacheco, J.S. David, M.I. Ferreira, J.S. Pereira and R. Tavares. 1996. Transpiration of a 64 year old maritime pine stand in Portugal 1. Seasonal course of water flux through maritime pine. Oecologia 107:33-42.

Lu, P., P. Biron, N. Breda and A. Granier. 1995. Water relations of adult Norway spruce (Picea abies (L.) Karst.) under soil drought in the Vosges Mountains: water potential, stomatal conductance and transpiration. Ann. Sci. For. 52:117-129.

Lu, P., P. Biron, A. Granier and H. Cochard. 1996. Water relations of adult Norway spruce (Picea abies (L.) Karst.) under soil drought in the Vosges Mountains: whole-tree hydraulic conductance, xylem embolism and water loss regulation. Ann. Sci. For. 53:113-121.

Meinzer, F.C. and D.A. Grantz. 1991. Coordination of stomatal, hydraulic, and canopy boundary layer properties: Do stomata balance conductances by measuring transpiration. Physiol. Plant. 83: 324-329.

Meinzer, F.C., J.L. Andrade, G. Goldstein, N.M. Holbrook, J. Cavelier and P. Jackson. 1997. Control of transpiration from the upper canopy of a tropical forest: the role of stomatal, boundary layer and hydraulic architecture components. Plant Cell Environ. 20: 1242-1252.

Meinzer, F.C., J.H. Fownes and R.A. Harrington. 1996. Growth indices and stomatal control of transpiration in Acacia koa stands planted at different densities. Tree Physiol. 16:607-615.

Mencuccini, M., S. Mambelli and J. Comstock. 2000. Stomatal responsivness to leaf water status in common bean (Phaseolus vulgaris L.) is a function of time of day. Plant Cell Environ. 23: 1109-1118. 
Mohr, H. and P. Schopfer. 1995. Light dependent control of stomatal aperture. In Plant Physiology. Springer-Verlag, Berlin, 629 p.

Monteith, J.L. 1965. Evaporation and environment. Symp. Soc. Exp. Biol. 19:205-234.

Monteith, J.L. 1981. Evaporation and surface temperature. Q. J. R. Meteorol. Soc. 107:1-27.

Monteith, J.L. 1995. A reinterpretation of stomatal responses to humidity. Plant Cell Environ. 18:357-364.

Oren, R. and D.E. Pataki. 2001. Transpiration in response to variation in microclimate and soil moisture in southeastern deciduous forests. Oecologia 127:549-559.

Oren, R., N. Phillips, B.E. Ewers, D.E. Pataki and J.P. Megonigal. 1999. Sap-flux-scaled transpiration responses to light, vapor pressure deficit, and leaf area reduction in a flooded Taxodium distichum forest. Tree Physiol. 19:337-347.

Oren, R., J.S. Sperry, B.E. Ewers, D.E. Pataki, N. Phillips and J.P. Megonigal. 2001. Sensitivity of mean canopy stomatal conductance to vapor pressure deficit in a flooded Taxodium distichum $\mathrm{L}$. forest: hydraulic and non-hydraulic effect. Oecologia 126:21-29.

Penman, H.L. 1948. Natural evaporation from open water, bare soil and grass. Proc. R. Soc. Lond. 193:120-146.

Raschke, K. 1979. Movements of stomata. In Physiology of Movements. Encyclopedia Plant Physiology. Eds. W. Haupt and M.E. Feinleib. Springer-Verlag, Berlin, pp 383-441.

Scholander, P.F., H.T. Hammel, E.D. Bradstreet and E.A. Hemmingsen. 1965. Sap pressure in vascular plants. Science 148: 339-346.

Schroeder, J.I. and R. Hedrich. 1989. Involvement of ion channels and active transport in osmoregulation and signaling of higher plant cells. Trends Biochem. Sci. 14:187-192.

Sellin, A. 1998. The dependence of water potential in shoots of Picea abies on air and soil water status. Ann. Geophys. 16:470-476.

Sharpe, P.J.H., H. Wu and R.D. Spence. 1987. Stomatal mechanics. In Stomatal Function. Eds. E. Zeiger, G.D. Farquhar and I.R. Cowan. Stanford University Press, Stanford, CA, pp 91-114.

Shashidhar, V.R., T.G. Prasad and L. Sudharshan. 1996. Hormone signals from roots to shoots of sunflower (Helianthus annuиs L.): moderate soil drying increases delivery of abscisic acid and depresses delivery of cytokinins in xylem sap. Ann. Bot. 78:151-155.

Sperry, J.S., N.N. Alder and S.E. Eastlack. 1993. The effect of reduced hydraulic conductance on stomatal conductance and xylem cavitation. J. Exp. Bot. 44:1975-1982.

Taiz, L. and E. Zeiger. 1998. Plant physiology. Sinauer Associates, Sunderland, MA, 794 p.
Tardieu, F. and W.J. Davies. 1993. Integration of hydraulic and chemical signalling in the control of stomatal conductance and water status of droughted plants. Plant Cell Environ. 16:341-349.

Tardieu, F., J. Zhang and D.J.G. Gowing. 1993. Stomatal control by both ABA in the xylem sap and leaf water status: a test model for droughted or ABA-fed field-grown maize. Plant Cell Environ. 16:413-420.

Tyree, M.T. 1988. A dynamic model for water flow in a single tree: evidence that models must account for hydraulic architecture. Tree Physiol. 4:195-217.

Tyree, M.T. and S. Yang. 1990. Water-storage capacity of Thuja, Tsuga and Acer stems measured by dehydration isotherms. Planta 182:420-426.

Van Kraalingen, D.W.G. 1990. Implications of non-uniform stomatal closure on gas exchange. Plant Cell Environ. 13:1001-1004.

Whitehead, D. 1998. Regulation of stomatal conductance and transpiration in forest canopies. Tree Physiol. 18:633-644.

Whitehead, D., N.J. Livingston, F.M. Kelliher, K.P. Hogan, S. Pepin, T.M. McSeveny and J.N. Byers. 1996. Response of transpiration and photosynthesis to a transient change in illuminated foliage area for a Pinus radiata D. Don tree. Plant Cell Environ. 19:949-957.

Williams, M., E.B. Rastetter, D.N. Fernandes, M.L. Goulden, S.C. Wofsy, G.R. Shaver, J.M. Melillo, J.W. Munger, S.M. Fan and K.J. Nadelhoffer. 1996. Modelling the soil-plant-atmosphere continuum in a Quercus-Acer stand at harvard forest: the regulation of stomatal conductance by light, nitrogen and soil/plant hydraulic properties. Plant Cell Environ. 19:911-927.

Wiltshire, J.J.J., C.J. Wright, J.J. Colls and M.H. Unsworth. 1995. Effects of heat balance stem flow gauges and associated silicone compound on ash trees. Agric. For. Meteorol. 73:135-142.

Wullschleger, S.D., F.C. Meinzer and R.A. Vertessy. 1998. A review of whole-plant water use studies in trees. Trees 18:499-512.

Zweifel, R. 1999. The rhythm of trees-water storage dynamics in subalpine Norway spruce. ETH Zürich, Diss. No. 13391, 112 p.

Zweifel, R. and R. Häsler. 2001. Dynamics of water storage in mature, subalpine Picea abies: temporal and spatial patterns of change in stem radius. Tree Physiol. 21:561-569.

Zweifel, R., H. Item and R. Häsler. 2000. Stem radius changes and their relation to stored water in stems of young Norway spruce trees. Trees 15:50-57.

Zweifel, R., H. Item and R. Häsler. 2001. Link between diurnal stem radius changes and tree water relations. Tree Physiol. 21:869-877. 